\title{
Increasing regional competitiveness through rural tourism (by example of Tyumen Region)
}

\author{
Krasovskaya Nadezhda Viktorovna \\ Financial and Economic Institute \\ Tyumen State University \\ Tyumen, Russia \\ Nadezda_3161@inbox.ru
}

\author{
Zamuraeva Larisa Evgenyevna \\ Financial and Economic Institute \\ Tyumen State University \\ Tyumen, Russia \\ Lzamuraeva@rambler.ru
}

\author{
Danilova Elena Pavlovna \\ Financial and Economic Institute \\ Tyumen State University \\ Tyumen, Russia \\ danilovaep@rambler.ru
}

\begin{abstract}
Regional competitiveness is currently the primary topical concern in Russia due to the country's disadvantaged economic and political situation in the world. Rural tourism in Tyumen region is the research object of the article. The subject of study is the rate and prospects of the development of rural tourism as a factor of ensuring competitiveness of Tyumen Region. The objective of the study is the identification of factors and rates of the development of rural tourism in Tyumen Region and formulation of recommendations on how to increase regional competitiveness. The hypothesis of the study is the assumption of Tyumen Region's potential in the development of rural tourism which could serve as a major impetus to the competitiveness of the Tyumen Region. The authors consider such methods as factor analysis, individual expert survey, evaluation of the level of the development of rural tourism in the region. The result of the research is the development of the rural tourism's potential and development of the evaluation algorithm.
\end{abstract}

Keywords - rural tourism; regional competitiveness

\section{INTRODUCTION}

According to the research carried out by the World Economic Forum, Russia was ranked $43^{\text {rd }}$ among 138 countries [1] in terms of global competitiveness, sharing the same ranking as those of Kuwait, India, Malta, Indonesia, Panama, Italy, Mauritius, Portugal, South Africa and Bahrain.

The index incorporates such indicators as quality of institutions, infrastructure, macroeconomic stability, health and primary education, higher education and professional development, efficiency of tradable goods and services, labour market efficiency, the level of technological development, the size of the domestic market, firm competitiveness and innovative potential.

The current situation in world economics is that a country's orientation exclusively to the raw-materials potential is inadequate for its competitiveness and economic growth.
Countries that claim to be leaders in world economics are fundamentally restructuring their real economy by promoting high-tech industries and the development of services.

There is a direct correlation between terms of competitiveness in Russia and the competitiveness of its regions. Hence, the problem of renovating regional economy is particularly relevant for Tyumen Region, with over $50 \%$ of its GDP, comprising mineral extraction, which signifies its focus on raw materials.

According to a report "Investment appeal of regions 2016: high-risk areas", Tyumen region is placed in the "low potential-moderate risk" area [2]. Ranks of investment potential components are as follows: labour - 32, consumption - 27, production - 20, financial - 27, institutional - 24, innovative - 23, infrastructure - 63, national resource - 45, tourism - 29. At the same time, the general potential rank has declined with an overall loss of three positions in 2016 compared to 2015.

The rank results indicate a long-felt need for developing industries apart from the oil and gas industry. Experience of such foreign countries as France, Italy, Spain, Germany, Cyprus, Greece shows that rural tourism is one of the catalysts for economic development. By popularity, it ranks second after seaside holiday; its specific weight is $20-30 \%$ in a total amount of income from tourism.

In this regard, the hypothesis of the research is that Tyumen region has the potential for the development of rural tourism as an essential factor of its competitiveness.

In Russia this type of tourism has gained the development at the beginning of the 21 st century owing to the fashion for a healthy lifestyle, healthy nutrition, natural, ecological clean food, etc. gaining popularity among citizens.

Most often in literature it is called "rural tourism", "agrotourism", "ecotourism", "green tourism". Owing to the fact that the concept "rural tourism" is fixed in "The strategy 
of sustainable development of rural territories of the Russian Federation until 2030" and in the Federal target program "Development of Internal and Entrance Tourism in the Russian Federation (2011-2018)" besides this kind of activity it will also be an object of a research of this article.

The analysis of regulation and scientific sources has shown that, first of all, there is no clear definition of "rural tourism" in Russian legislation, and secondly, authors' opinions on the definition differ.

Authors have carried out the review of works on the matter and has revealed differences of opinion of researchers.

Some researchers assume that such terms as "rural tourism", "agro-tourism", "eco-tourism", etc. are equivalent and are only linked to recreation in rural areas [3-5].

For example, Vlasenko O.V. considers that rural tourism "includes a complex of agrotourist services, such as observation and care of pets and plants, riding a horse, organic farm food using agricultural production of local production and crafts, acquisition of souvenir products, etc." [3].

However, the authors agree with those who distinguish the terms [6-12].

It is necessary to agree, for example, with Gvarliani T. E. and Borodin A.N. defining rural tourism as a "group of functional types of tourist activity which can be carried out in rural areas and include activity of the persons who are outside their usual environment, who are traveling and are staying in this area for a holiday and for other purposes" [7].

The authors' notion analysis of rural tourism indicated its significant markers:

1) type of visited territory - rural area;

2) content - functional types of tourism activities in rural area: agricultural, hunting, environmental, recreational, recuperative, cultural, sports, fishing, ethnic, religious;

3) objective - recreation and other objectives;

4) rural way of life;

5) traditional dishes and drinks;

6) type of premises - single-storey or low-rise premises with traditional interior and planning [13].

\section{METHODS AND RESEARCH RESULTS}

Tyumen region has the considerable potential of successful development of a competitive tourist branch.

In 2014, the number of the served tourists in the region was 160509 people, including those who travelled across the Russian Federation - 27969 people, Tab. I.

TABLE I. THE NUMBER OF THE SERVED TOURISTS IN TYUMEN REGION IN 2005-2014 [15]

\begin{tabular}{|l|c|c|c|}
\hline & \multicolumn{3}{|c|}{ Years } \\
\cline { 2 - 4 } & $\mathbf{2 0 0 5}$ & $\mathbf{2 0 1 3}$ & $\mathbf{2 0 1 4}$ \\
\hline $\begin{array}{l}\text { The number of served tourists - in } \\
\text { total, people: }\end{array}$ & 51178 & 166076 & 160509 \\
\hline $\begin{array}{l}\text { Including those travelling across the } \\
\text { Russian Federation }\end{array}$ & 17511 & 19019 & 27696 \\
\hline
\end{tabular}

Apparently, Tab. 1 shows that the total amount of tourist flow in Tyumen region tends to reduce owing to negative impact of macroeconomic and political factors. However, the number of the tourists who are carrying out trips across the Russian Federation increases every year (in 2014 there was a growth by $45.6 \%$ in comparison with 2013 ).

Intensive development of the tourism industry in Tyumen region will happen owing to the offer of new tourist products. According to the authors, rural tourism possesses great opportunities for attraction of domestic and foreign tourists to the region.

Development of an algorithm of assessment of its potential and development is relevant for a solution of the problem of competitiveness increase of rural tourism of the region.

This algorithm assumes consecutive development and realization of a package of measures which purpose consists in definition and permission of internal and external contradictions, deduction of balance and minimization of its risks when internal and external factors change by means of economic, financial, organizational and other actions.

The algorithm of assessment of potential and development of rural tourism presented by authors of work has to conform to certain requirements that are the conditions obligatory for performance:

1. Use of complex and system approaches for assessment of potential and development of rural tourism allowing considering in full all factors.

2. It is expedient to present the process of formation of this algorithm in the form of concrete instructions and instructions for implementation.

3. Potential of development is dynamic characteristics which under the influence of various external and internal factors constantly changes. Therefore evaluating and the analysis of dynamics of this indicator of branch in time will be logically true. As temporary selection of an initial indicator by authors of work, it is offered to use for 1 year.

4. This algorithm has to be rather simple from the point of view of the implementation which is not demanding attraction of an additional number of highly qualified specialists and expenses of a temporary resource, but on the other hand, to use possibilities of modern methods and tools.

5. On the offered algorithm depending on the level of development of rural tourism, concrete actions have to be developed for the increase in its potential of development.

The authors have proposed a three-phase algorithm of evaluating the development rate and the potential of rural tourism in Tyumen region, Fig. 1. 


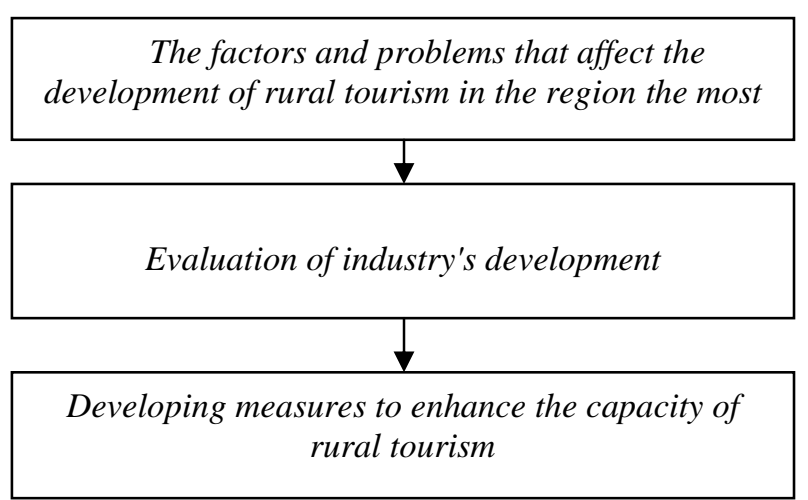

Fig.1. The algorithm of evaluating the development rate and the potential of rural tourism in Tyumen region

The first stage includes determining the factors and problems that affect to the largest degree the development of rural tourism in the region.

The second stage involves evaluation of industry's development.

The third stage involves developing measures to enhance the capacity of rural tourism. Implementation of the algorithm allows identifying rates and perspectives of the development of rural tourism.

During the first stage, the combination of factors was divided into two groups: motivating and limiting.

The first group is motivating factors.

1. Natural and climatic.

Tyumen region has unique natural and climatic resources.

The region is situated in the centre of Eurasia, stretching from the Republic of Kazakhstan to the coasts of the Arctic Ocean. A large part of the area is covered by taiga, foreststeppe with birch coppice is typical for the southern districts, marsh areas and salt marshes can also be found.

The relief is flat. The elk, the brown bear, the glutton, the wolf, the fox, the squirrel, the chipmunk, columns live in the taiga. The sable, the wood grouse, the hazel grouse, the black grouse are characteristic of the forest-steppe. During the summer period, there are a lot of waterfowl (geese, ducks). The rivers and lakes are rich with fish (about 30 types): sterlet, Siberian sturgeon, nelma, burbot, ide, etc.

The subsoil of the region contains mineral water that varies in its curative effects and quality. Considerable resources of curative mud are concentrated in the lakes.

In the south of Tyumen Region and in Khanty-Mansiysk Autonomous Region the climate is temperate (continental). The Arctic climate is in the north, in Yamal Nenets Autonomous Region, in the center - sub-arctic (maritime), in the south - Atlantic-continental.

Two state sanctuaries of federal importance were built in order to preserve the nature of the region: the Tyumen sanctuary and the Belozersk sanctuary; 33 sanctuaries of regional importance; 29 nature monuments were put under protection.
All this has allowed one to organize in the territory of the subject such ecotours as "A nature sanctuary "Of Maryino the gorge" (Isetsky district), "The archaeological complex "Ingalsky Valley" (on a joint of Isetsky, Yalutorovsk, Uporovsky districts and the Zavodoukovsky district), "Reserved hillocks" (The Ishim district), "On the Irtysh mountains" (The Tobolsk district), "On mysterious lakes" (Vikulovsky district), etc.

\section{Cultural and historical.}

The population of Tyumen region, including the rural population, is multinational: $73,3 \%$ of the population are Russians, 7,5\% - Tatars, 4,9\% - Ukrainians, $1 \%$ - Nenets, $0,9 \%$ - Khanty, etc. [14]

This is the result of khanty's, mansy's, nenets' and tatar's habitation in the region before Siberia's accession to the Russian State (the end of the XVI century).

With further conquering, there was an influx of Cossacks, immigrants from the central regions of Russia due to the land crisis and the emancipation reform of 1861, retired soldiers, exiles, Old-Believers and other types of population. Besides, Tyumen region was of strategic significance for the country during and after the Great Patriotic War.

The industrial conquest of Siberia in the mid-1960s, which led to the migration of the population on its territory from all the former USSR republics, was an important turning point in the development of the region.

\section{Socio-demographic.}

Rural tourism can be an alternative non-agricultural form of employment of rural population which could resolve social and economic problems.

By the end of 2014, there were 29 cities, 38 districts, 28 urban villages, 1483 rural population centres (1238 in the south of the region, 165 in the Khanty-Mansi Autonomous District, 80 in the Yamal-Nenets Autonomous District) [15].

In 2016, Tyumen region (without autonomous regions) had the highest total agricultural production per capita rate in Urals Federal District and the region was ranked last by the index of agricultural production. [14].

Besides, small business was developed in the rural areas of the region. So in 2014, the proportion of agricultural output by peasant farms and sole proprietors was $6.8 \%$ against $3.6 \%$ in 2005 [15].

718.1 thousand people lived in rural areas of Tyumen region in 2014, which makes $20.2 \%$ of the entire population of the region (in comparison, in 2000 the percentage was 23\%) [15]. Thus, a negative growth of the percentage of rural area population can be noted.

There is a decrease of active working age people in rural areas. Particularly, in 2015, the share of active working age rural population has decreased from $58.3 \%$ to $57.3 \%$ in comparison with 2014. The percentage of people over their employment age has increased from $19 \%$ to $19.7 \%$ over the same period.

The deteriorating demographical percentage of rural population has caused a decrease of the total economic rate of 
the agriculture as a whole. Thus, the percentage of the sector in Gross Regional Product has decreased by a factor of 1.5 (from $2.09 \%$ to $1.4 \%$ ). The agricultural production index in 2015 was $98.8 \%$ in comparison with 2014 [14].

However, despite the decrease of agricultural products' growth rate in Tyumen region and able-bodied rural population's migration to the city, the region (specifically, the south] is able to organize various functional types of rural tourism.

Competitive multisector agriculture contributes to that cause. Dairy and beef farming, poultry farming, reindeer husbandry, trapping as well as growing grain and feedstocks, potatoes and vegetables are developed on the territory of the constituent entity.

\section{Economical.}

Rural tourism has a relatively low cost price in comparison with other types of tourism which makes it attractive for both business and potential clients.

\section{Demand factors.}

Lately there has been a growing demand for the industry's services from potential tourists, which is caused by progressing urbanization, growing popularity of healthy lifestyle, proper nutrition, farmers products and by growth of patriotism and interest for the country's history.

Besides, the catalyst for growth of interest in rural tourism was the macro economic and political problems in the country and in the world: economic crisis, a decrease in population's real income, devaluation of the national currency and deterioration of the political situation.

\section{Legislative.}

Legal instruments that show the importance of developing rural tourism have been developed at the federal level.

The second group - limiting factors.

\section{Marketing.}

Firstly, there is a lack of promotion of rural tourism of Tyumen region as a tourism product on Russian and worldwide market which leads to a low awareness of potential consumers.

Secondly, there are no cheap, quality and complex tourism products of rural tourism and there is a lack of the necessary developed tourists' infrastructure.

Thirdly, a low quality of service is inherent in rural tourism.

\section{Natural and climatic.}

The seasonal demand, peaking in summer and in winter, exerts a strong influence on the segment.

\section{Socio-demographic.}

A considerable outflow of the economically active population from the village to the city, low motivation of rural population for developing entrepreneurship, low salaries in rural areas, shortage of personnel in agriculture should be attached to this factor group.

\section{Logistical.}

High percentage of depreciation of tourists' accommodation in rural areas.

\section{Legislative.}

Firstly, there is a lack of federal acts regulating rural tourism.

Secondly, a lack of state standards for tourists' activity and servicing in rural areas is observed.

\section{Economical.}

There is deficiency of State financial support of rural tourism and investment in development of tourism complexes.

The factors of development of rural tourism of Tyumen region allocated with authors have allowed one to define threats and opportunities, strong and weaknesses of this branch.

Threats to the studied branch are:

1. Lack of the federal laws regulating activity of rural tourism.

2. Lack of state standards and standards for implementation of tourist activity and service in rural areas.

3. Lack of the state financial support of rural tourism at the regional level.

4. Lack of investments for development of tourist's complexes.

5. Lack of the directions of training of students in the field of rural tourism in average and higher educational institutions of area.

6. Discrepancy of cost and quality of a tourist's product.

7. The competition from other types of tourism.

It is possible to contribute the following to the opportunities of rural tourism:

1. The growing demand from potential tourists.

2. The increasing popularity of farmer products, healthy nutrition, a healthy lifestyle.

3. Growth of internal tourism in the Russian Federation owing to aggravation of a political situation in the world, an economic crisis, a decrease in real income of the population, devaluation of national currency.

4. Polar climatic conditions in the South and the North of the area.

5. Existence of stocks of mineral water and dirt with medicinal properties.

6. Rich historical and cultural heritage.

7. Unique customs of indigenous people of the North of the region.

8. Multinational structure of country people.

9. Existence of the federal standard and legal documents specifying the importance of development of tourism in rural areas.

10. The state support at the regional level. 
11. Growth of patriotism, interest of the population in history of Russia.

Based on the above-mentioned facts, main problems of the development of rural tourism in the Tyumen region were identified.

Firstly, despite the region possessing significant natural and climatic, historical and cultural, recreational and socioeconomic resources for the development of rural tourism, its potential is not being harnessed.

Only two successful enterprises working in that sphere can be noted: "Turnaevo peasant farm" (Nizhnya Tavda district, Turnaevo village) and an ostrich farm "Tyumenskiy straus" (Chickcha village].

Secondly, there is a lack of State support for rural tourism entities in the financial, educational, promotional field, etc. due to its false equating with hunting, fishing, ecological and other tourism industries in the regional legal instruments.

Thirdly, rural guest houses are not used for tourists' accommodation in the region.

Fourth, there is hardly any guided tour service with a view to familiarize with national observances and to teach traditional handicraft, etc.

Fifth, the market lacks any proposals to visit rural farms with a view to familiarize with their work and give cooking master classes.

Sixth, there are no stylized "ethnic villages" in Tyumen region.

Seventh, the usage of a limited number of functional types of rural tourism by market entities. Generally, hunting, fishing, sports, recreational and ecological types are used. The immense potential of agricultural, curative, educational, ethnical and religious types of tourism is not used in the region.

Eighth, a lack of official statistics on rural tourism in the region does not allow fully estimating the efficiency of the industry and, thereby, attracting investment for development.

Despite existence of a large number of problems in development of rural tourism of the region, this branch has also a number of strengths.

1. Various functional types of rural tourism.

2. Rather low cost in comparison with beach and other types of tourism.

The level of rural tourism's development in the region is identified at the second stage of the algorithm.

The authors offer to highlight to the following levels: basic, transitory, increased. The basic level of an industry's development is characterized by a deficiency of a complex touristic product and appropriate infrastructure. An increased level demands a complete development of the industry with a creation of the regional cluster.

The identification of the development of rural tourism in Tyumen region was carried out based on a method of an individual expert survey of ten Tyumen travel company managers. All the experts agreed that the researched industry is on the basic level of development in the region, but it is possible for it to develop.

At the third stage of the algorithm, the authors have proposed events aiming to increase the potential for developing rural tourism in the region.

The establishment of rural tourism in Tyumen region can be categorized into two stages.

The first stage is initial. It is characterized by the development of rural tourism on the basis of guest houses of villagers which will provide a limited range of accommodation, nutritional, tourist and guided tour services.

Various actions are necessary for accomplishing that stage:

- developing "Regional rural tourism development programme in Tyumen region";

- providing state financial and organizational support for the entrepreneurs starting touristic business in rural areas;

- educational master classes and workshops on organizing and maintaining rural tourism for owners of guest houses and on organizing study tours to family farms in Moscow and Leningrad oblast, Altai and other regions in Russia, including the foreign regions;

- providing state support for promoting rural tourism, for developing a catalogue of rural guesthouses, "Practical guidance on organizing and carrying out rural tourist business in Tyumen region", advertising booklets; for arrangement of advertising tours for travel companies; for placing the information on the "Tourist resources of Tyumen region" website, etc.

The second stage of developing rural tourism in the region is advanced.

Within its framework, tourist complexes in the form of "national villages" or stylized rural shelters (Russian, Tatar, people of the Far North) will operate as well as the guesthouses, providing complex tourism product that includes the following types of service:

- accommodation and nutrition;

- participation in the agricultural production;

-visiting peasant farms (agricultural industries) to get acquainted with their work;

-participation in cooking master classes on traditional dishes and beverages;

- active types of recreation: hunting, fishing, picking mushrooms, horse-riding, snowmobiling etc.;

- ecological tours;

- pilgrimage to sacred places;

- visiting thermal springs;

- curative service with the use of local natural means: massage, SPA-procedures etc;

- other additional service.

A substantial investment is necessary to realize this stage, therefore a significant financial state support is also necessary.

The algorithm developed by authors has advantages:

1) it allows one to make assessment of a condition of rural tourism in a complex and to consider all its factors; 
2) it can be used in any industry as algorithm stages have universal character.

\section{CONCLUSION}

The study has shown that rural tourism in Tyumen region is at the basic stage of development. However, the industry has all the necessary capability for intensive development.

Thus, the algorithm that was proposed by the authors has confirmed the hypothesis that Tyumen Region has the necessary potential for development of rural tourism as an important factor of ensuring its competitiveness.

\section{References}

[1] The Global Competitiveness Index-2016. URL: http://gtmarket.ru/ratings/global-competitiveness-index/info (date of access: 01.06.2017).

[2] Investment attractiveness of regions-2016: areas of increased risk. URL: http://raexpert.ru/ratings/regions/2016/ (date of access: 01.06.2017).

[3] O.V. Vlasenko, "Agrorekreatsionny potential and possible directions for development of agrotourism in Irkutsk region", Proceedings of $1^{\text {st }}$ International Research and Practical Conference, pp.190-195, June 2007 [Agrarian and economic science on problems of innovative development of agro-industrial production, p. 410, 2007].

[4] A.B. Zdorov, Agritourist complex: forecasting for regional development, Moscow: Tourist Publ., 2007, p.168.

[5] N. Srisomyong and D. Meyer, "Political economy of agritourism initiatives in Thailand”, Journal of Rural Studies,41, pp. 95-108, 2015.
[6] N.A. Vinigorova, "Rural tourism as a factor in the development of domestic tourism", Bulletin of magistracy, 11-3 (50), pp.99-101, 2015.

[7] T.E. Gvarliany and A.N.Borodin. "Rural and agricultural tourism as specific types of tourism", Terra Economicus, 9, 4-3, pp.61-65, 2011.

[8] A.N. Poluhina and A.V. Lezhnin, "Innovative methods of development of the region: rural tourism", Economic sciences, 125, pp.127-129, 2015.

[9] J.W. Kloeze, The Benefits of Rural Tourism, the Role of the State, and the Aspects of Training and Co-operation. Rural Tourism Development in Bulgaria and in the Balkan Countries, Karlovo, 1994, pp.21-25.

[10] A. Fotiadis, S.-S.Yeh and T.-C.T.C. Huan, "Applying configural analysis to explaining rural-tourism success recipes", Journal of Business Research, 69(4), pp.1479-1483, 2016.

[11] F. Martinez-Roget, J.A.T. Moutela and J.C.E. Nunez, "Keys to the success of rural tourism: Evidence from tourist loyalty in the rede das aldeias do xisto", Revista Portuguesa de Estudos Regionais, 40 (1), pp.65-81, 2015.

[12] S. Neumeier and K. Pollermann "Rural tourism as promoter of rural development-Prospects and limitations: Case study from a pilot projectpromoting village tourism", European Countryside, 6 (4), pp.270296, 2014.

[13] N.V. Krasovskaya, "Rural tourism in region: main trends and opportunities for growth", Izvestiya Saint-Petersburg State Agrarian University, 44, pp.210-216, 2016.

[14] Regions of Russia. Main characterictics of the subjects of the Russian Federation. 2016, Moscow: Rosstat, 2016, p.671.

[15] Statistical Yearbook Tyumen Oblast. Vol. 1, Tyumen: Statistical summary. Territorial body of the Federal State Statistics Service of the Tyumen Oblast, 2015, p. 316. 